\title{
The Effect of Guessing on the Speech Reception Thresholds of Children
}

\author{
Asoka Moodley, B.Ed (Hons) MEd (Audiol.) F.C.P. \\ County Service for the Sensory Impaired \\ Audiology Education Department, Lincolnshire County Council \\ Lincolnshire, United Kingdom
}

\begin{abstract}
Speech audiometry is an essential part of the assessment of hearing impaired children and it is now widely used throughout the United Kingdom. Although instructions are universally agreed upon as an important aspect in the administration of any form of audiometric testing, there has been little, if any, research towards evaluating the influence which instructions that are given to a listener have on the Speech Reception Threshold obtained. This study attempts to evaluate what effect guessing has on the Speech Reception Threshold of children. A sample of 30 secondary school pupils between 16 and 18 years of age with normal hearing was used in the study. It is argued that the type of instruction normally used for Speech Reception Threshold in audiometric testing may not provide a sufficient amount of control forguessing and the implications of this, using data obtained in the study, are examined.
\end{abstract}

\section{OPSOMMING}

Spraakoudiometrie is 'n wesenlike aspek van die totale evaluering van gehoorgestremde kinders en word tans uitgebreid in die Verenigde Koninkryk aangewend. Daar word universeel saamgestem dat instruksies van wesenlike belang is in die uitvoering van alle vorme van oudiometriese toetsing. Beperkte navorsing is egter tot op hede uitgevoer om die invloed van die instruksies, wat aan die luisteraar verskaf word op die spraakontvangsdrempel te peil. Hierdie studie poog om die uitwerking van raai op die spraakontvangsdrempel van kinders te evalueer. 'n Steekproefvan 30 hoërskoolleerlinge tussen die ouderdomme van 16 tot 18 jaar, met normale gehoor, is in die studie benut. Daar word beweer dat die tipe instruksies wat standaard gebruik word in die bepaling van die spraakontvangsdrempel, nie voldoende beheer uitoefen oor raai nie. Die implikasies daarvan word ondersoek met behulp van die data wat in die studie verkry is.

In performing speech audiometry it is common to obtain two measures of speech performance: the speech reception threshold (SRT) and the speech discrimination score. The SRT is similar to the hearing threshold level for pure tones, because it is the lowest level at which the individual can just hear and repeat $50 \%$ of the test words. The discrimination score determines the person's ability to understand speech by measuring his capacity to distinguish the various phonemes of oral language at comfortable levels of loudness.

In general the speech reception threshold and the pure tone average of the speech frequencies serve as a reliability checkon each other, and should correspond closely.

It has been suggested (Carhart \& Porter, 1971) that averaging the pure tone thresholds at $500 \mathrm{~Hz}$ and $1 \mathrm{KHz}$, minus $2 \mathrm{~dB}$, adequately predicts the SRT from most audiometric configurations.

In clinical practice the audiologist considers that agreement between speech reception threshold and PTA of $\pm 6 \mathrm{~dB}$ is within acceptable limits (Oslen \& Matkin, 1979). When one measure deviates substantially from the other, it can be an indication that results are suspect, and that both pure tone and speech audiometry should be repeated.

Within the last thirty years, speech reception threshold (SRT) testing has come to play a prominent role in audiometry, mak- ing it one of the major audiometric tests available for the assessment of hearing. Consistent with the magnitude of importance attached to the SRT has been the great amount of research concerning numerous procedural variables that have been shown to influence the magnitude of SRT obtained for a given subject.

These include:

1. The form of the verbal stimuli used for the measurement of SRT (Harris, 1965).

2. The degree of sophistication a listener possesses with regard to vocabulary (Farrimond, 1962).

3. The degree of familiarity the listener has with the test stimuli (Oslen \& Matkin, 1979, Wilson \& Margolis, 1983).

4. The use of live voice versus recorded presentation (Beattie, Forrester \& Ruby, 1977).

Although instructions are universally agreed upon as an important aspect in the administration of any form of audiometric test, little, if any, research has been directed towards evaluating the influence which the instructions that are given to a listener have on the speech reception threshold obtained.

This study was concerned mainly with the possible influence that the factor of guessing, which is encouraged in essentially all suggested instructions for the speech reception threshold 
(Chalklin \& Ventry, 1964; Harris, 1965; Martin, 1975; Newby, 1972), may have on the resulting threshold for speech. This interest was fostered by the writer's observation that although all subjects are given similar instructions for the SRT, which include encouragement to guess on items of which they are uncertain, considerable variability seems to exist in the degree of guessing which actually takes place among individuals. Given this situation, it seems feasible to assume that those persons inclined to guess in an "aggressive" fashion, might obtain SRT decidedly different from the SRT obtained from those who choose not to engage in any guessing. The aim of this study was therefore to attempt to quantify the extent, if any, to which the factor of guessing may conceivably influence the magnitude of the SR'T.

\section{SUBJECTS}

Subjects for the study included 30 secondary school pupils, made up of 15 boys and 15 girls. The average age of the boys was 16.9 years and the average age of the girls was 17.2 years. The average age of the group as a whole was 17.5 years. The age range for the group was 16.2 years - 18.5 years. More details of the sample are shown in Table 1.

'To qualify as a subject each pupil had to be:

1. Between 16 and 18.5 years of age.

2. Not have any prior knowledge of the SRT procedure.

3. Possess air conduction pure tone thresholds of $20 \mathrm{~dB} \mathrm{HL}$, or better, in the test ear at the octave frequencies from $250-4000 \mathrm{~Hz}$.

Table 1: Number, age and sex of subjects taking part in study

\begin{tabular}{|cccc|}
\hline & & \multicolumn{2}{c|}{ AGE IN YEARS } \\
SEX & NO. & MEAN & RANGE \\
\hline Boys & 15 & 16.9 & $16.3-18.4$ \\
Girls & 15 & 17.2 & $16.2-18.5$ \\
Boys \& Girls & 30 & 17.5 & $16.2-18.5$ \\
\hline
\end{tabular}

\section{METHOD}

Each pupil was seen initially to determine whether or not he or she qualified for the study. Information concerning age and familiarity with the SRT was ascertained initially. Pupils meeting these two qualifications were then given both pure tone and SR' $T$ tests in one ear randomly selected for examination. Air conduction pure tone thresholds were obtained in the test ear at octave frequencies from $250-4000 \mathrm{~Hz}$.

After the completion of pure tone testing, SRTs were obtained in the same test ear. Each pupil was administered the SR'T procedure under two separate conditions.

In Condition 1 the SRT was obtained with the subjects being instructed NO'T TO GUESS ON ANY ITEMS OF WHICH THEY WERE UNSURE. For Condition 2 subjects were required to make a response for every spondee word presented. These two conditions were counterbalanced among subjects to control for any possible learning effects. Before formal testing began each subject was familiarised with the test item by having the individual read each of the 35 spondee words.

Instructions were then given to each subject based on the instructions offered by (Hopkinson, 1972). Minor modifications in these instructions were made to reflect the differences in the test procedures to be used with each of the two test conditions. The instructions for Condition 1 are given below.

"Words will be presented to you that have two parts: words like baseball, mushroom, and eardrum. The words will get softer and softer. Just repeat each word after you have heard it. Repeat each word you feel you have heard correctly. Do not guess if you feel unsure of a word. Are there any questions?"

The same instructions were used for Condition 2 with the appropriate modifications:

"Words will be presented to you that have two parts: words like baseball, mushroom, and eardrum. The words will get softer and softer. Just repeat each word after you have heard it. It is important that you make an attempt at every word, even those of which you are uncertain. Please respond on every test item, even if it is a guess. Are there any questions?"

\section{TEST MATERIALS AND PROCEDURE}

Speech reception thresholds were obtained using commercially available tapes of the Central Institute for the Deaf (CID) Auditory Test $\mathrm{W} / 1$. This consists of a list of 36 spondaic words, such as daybreak, birthday. Six lists of $W / 1$ are available, each list being a different scrabbling of the same 36 words. The $\mathrm{W} / 1$ recording attenuates the spondee $10 \mathrm{~dB}$ relative to the carrier phrase "Say the word". This means that the carrier phrase has been recorded approximately $10 \mathrm{~dB}$ above the average level of the words.

All pure tone and speech audiometry was conducted in a well carpeted room, measuring $15 \times 18$ feet, free from extraneous noise and where the recorded ambient noise was no more than $40 \mathrm{dBA}$ at various intervals during the course of the testing.

All signals were generated by a Kamplex TA 155 Diagnostic Audiometer and transduced to each subject via TDH-39 earphones mounted in MX41/AR cushions.

Procedures described by (Martin \& Pennington, 1971) with a $5 \mathrm{~dB}$ increment were utilized for establishing each SRT.

The SRT for each subject was obtained using a descending! method, rather than an ascending method. Speech signals: were presented at a comfortable level above threshold to fami-', liarise the listener with the words and the task. 'The level was: then decreased in $5 \mathrm{~dB}$ steps, presenting one to three words at each level decrement until a word was missed. At this point the stimulus level was raised $10 \mathrm{~dB}$ and then lowered in $5 \mathrm{~dB}$ steps, presenting 3-6 spondees with each change in stimulus level. The level at which $50 \%$ of the spondees were correctly repeated was recorded as their Speech Reception Threshold (SRT).

\section{RESULTS}

The mean pure tone results obtained for the group of 30 subjects included in the study as well as the pure tone averages are presented in Table 2 .

Mean pure tone values obtained as a function of sex revealed some difference in auditory acuity between male and female subjects; the thresholds generally were better for female subjects for all frequencies tested, with the greatest difference between male and female subjects occurring at $2000 \mathrm{~Hz}$ and 
$4000 \mathrm{~Hz}$. These findings are in good agreement with results obtained by an investigation by Corso (1968), where statistically significant differences in threshold values were found between male and females, which are similar to those found in this study.

The mean SRTs obtained under conditions 1 and 2 are presented in Table 3. These results are in good agreement with the pure tone data, with females yielding slightly better SRTs under both test conditions. An overall threshold difference in SRT of 8.40 was observed between conditions 1 and 2 , with condition 2 yielding the best SRTs. Similar difference values were observed for the male and female subjects under these two test conditions.

The SRT data obtained under conditions 1 and 2 were subject to a two-way analysis of variance procedure (Winer, 1971). This was done to determine whether any statistically significant differences in SRT existed between these two conditions as a function of sex and type of instructions, or as a result of any interaction between these variables. The analysis indicated a significant $F$ value for $\operatorname{sex}(p<0.05)$ and type of instructions for the SRT $(\mathbf{p}<0.01)$, while no significant interaction was observed between these two variables.

The significant $F$ Value for the factor of sex is to be expected, due to the superior auditory acuity possessed by the female subjects in this investigation. The strong significance of the $F$ ratio for the type of instructions clearly indicates that the factor of guessing will influence the SRT obtained by a magnitude which is statistically and clinically significant.

\section{DISCUSSION}

The results of this study may be of relevance in the determination of the FRT in a clinical environment, and may also be of use to teachers of the hearing impaired in their routine audiological assessment of hearing impaired children.

Previous research dealing with other variables associated with the administration of the FRT (Tillman \& Jerger, 1959;
Chalklin \& Ventry, 1964; Siegenthaler \& Smith, 1961) has generally concluded that variables such as practice in hearing spondees at or near threshold, live voice versus recorded test stimuli, and use of two or five $\mathrm{dB}$ increment in the measurement of the SRT, have no strong clinical implications, since these variables were found to influence the SRT by magnitudes of only 1-2dB. However, other research by (Tillman \& Jerger, 1959) on familiarization with the test stimuli, has demonstrated that when a factor influences the SRT by an amount greater than this, it then becomes clinically relevant. Therefore, the implication is that the $8.40 \mathrm{~dB}$ difference found to be associated with guessing in the present study, makes it important that this variable be controlled in some fashion during the administration of the SRT.

The type of instruction normally used for the SRT in audiometric testing may not provide a sufficient amount of control for guessing. Although no formal investigation has been conducted to determine the precise extent to which individuals engage in guessing while undertaking the SRT test, personal experience would suggest a considerable amount of variability in the amount of guessing that individuals actually engage in during the test. Some children will guess on spondee items when they have heard little, if any, of the acoustic information in a given word, while others are prone not to engage in any guessing and will respond to the test stimuli only when they are relatively confident that they have heard the word presented. These extremes exist even though a common set of instruc tions, which encourage guessing, are used during testing. There seems to be too much latitude in the manner in which a given individual reacts and responds to currently used instructions for the SRT: relative to the variable of guessing. This allows for two different individuals with identical hearing acuity to conceivably obtain significantly different Speech Reception Thresholds, and also makes it potentially possible for a given person to obtain two significantly different speech reception thresholds, all because of the degree to which guessing occurs during the testing.

This suggests that some modification in the instructions should be considered that will provide for more control of this impor-

Table 2: Mean pure tone thresholds in $\mathrm{dB}$ HL for the 15 males and 15 females in this study. Standard deviations are also included.

\begin{tabular}{|c|c|c|c|c|c|c|}
\hline FREQUENCY (HZ) & $\begin{array}{c}\text { MALES } \\
(\mathrm{N}=15)\end{array}$ & SD & $\begin{array}{l}\text { FEMALES } \\
(\mathrm{N}=15)\end{array}$ & SD & $\begin{array}{l}\text { COMBINED } \\
(\mathrm{N}=30)\end{array}$ & SD \\
\hline $\begin{array}{r}250 \\
500 \\
1000 \\
2000 \\
4000\end{array}$ & $\begin{array}{l}4.00 \\
4.00 \\
1.34 \\
4.00 \\
6.66\end{array}$ & $\begin{array}{l} \pm 9.1 \\
\pm \quad 9.86 \\
\pm 12.46 \\
\pm 14.54 \\
\pm 17.6\end{array}$ & $\begin{array}{l}0.66 \\
0.66 \\
2.00 \\
2.00 \\
0.66\end{array}$ & $\begin{array}{r} \pm \quad 7.04 \\
\pm \quad 7.04 \\
\pm \quad 9.42 \\
\pm 12.08 \\
\pm 12.22\end{array}$ & $\begin{array}{l}1.68 \\
1.68 \\
0.34 \\
1.00 \\
3.00\end{array}$ & $\begin{array}{l} \pm 8.60 \\
\pm \quad 8.34 \\
\pm 10.98 \\
\pm 13.48 \\
\pm 15.34\end{array}$ \\
\hline $\begin{array}{c}\text { PURE-TONE AVERAGE } \\
(500 \mathrm{HZ} \mathrm{IK} 2 \mathrm{~K})\end{array}$ & 3.12 & \pm 9.20 & 1.56 & \pm 6.40 & 0.78 & \pm 8.14 \\
\hline
\end{tabular}

Table 3: Mean SRT in AB HL for male and female subjects in the study under Condition 1 (no guessing) and Condition 2 (guessing required). Difference values are also given. Standard deviations are provided.

\begin{tabular}{|c|c|c|c|c|c|c|}
\hline & \multirow[b]{2}{*}{ CONDITION 1} & \multirow[b]{2}{*}{ SD } & \multirow[b]{2}{*}{ CONDITION 2} & \multirow[b]{2}{*}{ SD } & \multicolumn{2}{|c|}{ DIFFERENCE SD } \\
\hline & & & & & COND 1 & COND 2 \\
\hline$(N=15)$ & 2.66 & \pm 8.12 & 6.26 & +7.04 & 3.60 & \pm 1.84 \\
\hline Females $\quad(N=15)$ & 2.80 & \pm 5.60 & 10.66 & \pm 5.22 & 7.86 & \pm 2.32 \\
\hline Combined $(\mathrm{N}=30)$ & 0.06 & \pm 7.40 & 8.46 & \pm 6.48 & 8.40 & \pm 2.12 \\
\hline
\end{tabular}


tant factor. Serious consideration should be given to adopting a set of instructions that is similar to the instructions given to the subjects in this study during Condition 1 or 2 . Listeners should be presented with a situation where they have a very clear and definite responses pattern specified. For example, if an individual is instructed not to guess at any time and to respond only when he/she is absolutely sure of a given test stimulus, guessing will be essentially controlled. No practical means of totally controlling guessing with absolute certainty is available, but this does not seem to be a serious limitation.

Another important reason for the control of the guessing variable relates to the agreement observed between the Speech Reception Threshold (SRT) and the pure tone audiogram (PTA). Numerous researchers (Jerger, et al. 1959; Tillman \& Jerger, 1959; Carhart \& Porter, 1971) have investigated the agreement between these two indexes and have found it to be very close for listeners in which valid audiometric data have been obtained. Generally the SRT should be within $\pm 5 \mathrm{~dB}$ of the PTA for a given ear. Because of the stability of the agreement between the SRT and the PTA, it has been used as an important index of the validity of the data obtained on each of these two tests.

In this study the PTAs of the 30 subjects agreed more closely with the SRTs obtained under Condition 1, where no guessing was allowed. This comparison resulted in a mean PTA of $0.78 \mathrm{~dB} \mathrm{HL}$ and a mean SRT of $0.06 \mathrm{~dB}$ HL. If better agreement between these two indexes is desired, the results of this study suggest that consideration should be given to the elimination of guessing during the attainment of the Speech Reception Threshold (SRT).

\section{REFERENCES}

Beattie, R., Forrester, P., \& Ruby, B. Reliability of the Tillman-Oslen Procedure for determination of spondee threshold using recorded and live voice presentations. Journal of the American Audiological Soriety, no. 2, 159-162, 1977.

Carhart, R.\& Porter, L.F. Audiometric configuration and prediction of threshold for spondees. Journal of Speech and Hearing Research, $14,486-495,1971$.

Chalklin, J. \& Ventry, I. Spondee 'I'hreshold Measurement: a comparison of 2 and $5 \mathrm{~dB}$ methods. Journal of Speech and Hearing Disorders, 27, 47-59, 1964.

Corso, J. Proposed laboratory standard of normal hearing. Journal of the Acoustical Society of America, 30, 14-23, 1958.

Farrimond, T. Factors influencing auditory perception of pure tones and speech. Journal of Speech and Hearing Research, 5, 194. 204, 1962.

Harris, J. Speech Audiometry in A. Glorig Ed. Audiometry; principles and practices. Williams and Wilkins, Baltimore, M.D., 1965.

Hopkinson, N. Speech Reception Threshold in J. Katzed. Handbook of Clinical Audiology, Williams \& Wilkins, Baltimore, M.D., 1972.

Jerger, J., Carhart, R., Tillman, T., \& Peterson, J. Some relations between normal hearing for pure tones and for speech. Journal of Speech and Hearing Research, 2, 126-140, 1959.

Martin, F.N., \& Pennington, C.D. Current trends in audiometric practices. A.S.H.A. 13, 671-677, 1971.

Newby, H. Audiology, Prentice Hall, 1972.

Oslen, W.O., \& Matkin, N.D. Speech audiometry. In Rintleman, W.F. (ed.) Hearing Assessment. Baltimore: University Park Press, 1979.

Siegenthaler, B., \& Smith, D. Speech Reception Thresholds by different methods of test administration. Journal of the Acoustical Society of America, 33, 1802, 1961.

Tillman, T., \& Jerger, J. Some factors affecting the spondee thresholds in normal hearing subjects. Journal of Speech and Hearing Research, 2, 141-146, 1959.

Wilson, R.H., \& Margolis, R.H. Measurements of auditory thresholds for speech stimuli, Principles of Speech Audiometry, Konkle, D.F. \& Rintelmann, W.F. (ed), page 79-126, 1983.

Winer,B. Statistical Principles on Experimental Design, Mcriraw Hill New York, 1971. 